\title{
The paleoproterozoic post-tectonic granites of the Gavião Block: the example of Salininha monzogranite, Brumado, Bahia, Brazil
} Os granitos paleoproterozoicos pós-tectônicos do Bloco Gavião: o exemplo do monzogranito Salininha, Brumado, Bahia, Brasil

\author{
Rafael Gordilho Barbosa ${ }^{1}{ }^{\oplus}$, Johildo Salomão Figueiredo Barbosa' ${ }^{\circledR}$, \\ Michael Andrew Hamilton² (D), Jailma Santos de Souza de Oliveira1, Lucas de Queiroz Salles ${ }^{3}$ \\ ${ }^{1}$ Universidade Federal da Bahia - UFBA, Basic Geology Nucleus, Praça Igaratinga, 236, apt. 1.002, Pituba, CEP 41830-290, \\ Salvador, BA, BR (rafab.geologia@gmail.com; johildo.barbosa@gmail.com; jailmasouza@gmail.com) \\ University of Toronto, Toronto, ON, CA (mahamilton@es.utoronto.ca) \\ ${ }^{3}$ Universidade Federal da Bahia - UFBA, Salvador, BA, BR (lucassalles2008@gmail.com)
}

Received on January 26, 2017; accepted on November 12, 2018

\begin{abstract}
The Gavião Block is underlain by a variety of Archean orthogneisses and greenstone belts, intruded by a suite of syn-deformational and post-tectonic granitoids which ages of emplacement are poorly constrained between the Paleoand Mesoproterozoic. The Salininha monzogranite is a massive intrusion located approximately $50 \mathrm{~km}$ northwest of Brumado, south-central Bahia state, Brazil. The intrusion is representative of several post-tectonic felsic plutons in the Gavião Block. Their petrology, geochemistry and age have been largely unstudied. Salininha pluton is a roughly $16 \mathrm{~km}^{2}$ irregular, elongate body intruding strongly deformed and metamorphosed orthogneisses and migmatites of the Archean Gavião Complex. Modally, the Salininha rocks contain biotite as the major ferromagnesian accessory, besides lesser hornblende, muscovite, chlorite, zircon, opaques and epidote. They are slightly peraluminous rocks with high silica contents $(71.6-75.0 \mathrm{wt} \%)$, obtained by lithium tetraborate fusion inductively coupled plasma (ICP). The rocks have high concentration of $\mathrm{Rb}, \mathrm{Sr}$ and $\mathrm{Ba}(323,88$ and 1,155 ppm, respectively). These values were obtained by lithium tetraborate fusion (mass spectrometer-MS). The average value obtained for the La/Yb ratio was 18.83. Chondrite-normalized rare earth element (REE) patterns show a smooth, restricted range, with moderate light REE enrichment, but flat heavy REE patterns - all samples show pronounced negative Eu anomalies consistent with feldspar fractionation. Major and trace elements have trends, which indicate that crystal fractionation of plagioclase, K-feldspar and biotite - an important process during magmatic evolution of the pluton. The trace element data provided support to the classification of the Salininha monzogranite as a post-collisional intrusion. A representative sample has yielded an early Orosirian U-Pb (zircon) age of $2003 \pm 4 \mathrm{Ma}$, via chemical abrasion-isotope dilution-thermal ionization mass spectrometry (CA-ID-TIMS), consistent with an interpretation of the Salininha monzogranite as a post-tectonic intrusion in the southern Gavião Block.
\end{abstract}

Keywords: Gavião Block; Post-tectonic intrusion; Salininha Monzogranite; Bahia; Brazil.

\section{Resumo}

O Bloco Gavião possui como embasamento uma variedade de ortognaisses e greenstone belts intrudidos por um conjunto de granitoides sin-deformacionais e pós-tectônicos cuja idade de colocação é paleoproterozoica. O Monzogranito Salininha é uma intrusão maciça localizada a aproximadamente $50 \mathrm{~km}$ a noroeste da cidade de Brumado, centro-sul da Bahia, Brasil. A intrusão é representativa de um conjunto de diversos plútons félsicos pós-tectônicos do Bloco Gavião, cuja petrologia tem sido pouco estudada. O plúton Salininha é irregular e alongado e possui aproximadamente $16 \mathrm{~km}^{2}$, intrudindo ortognaisses e migmatitos fortemente deformados e metamorfisados do Complexo Gavião, de idade arqueana. Em termos modais, o monzogranito Salininha possui biotita como principal mineral acessório ferromagnesiano, além de pouca hornblenda, muscovita, clorita, zircão, opacos e epidoto. Essas rochas são levemente peraluminosas, com alto teor de sílica $(71,6-75,0 \mathrm{wt} \%)$. As rochas possuem altas concentrações de $\mathrm{Rb}$, $\mathrm{Sr}$ e $\mathrm{Ba}(323,88$ e 1.155 ppm, respectivamente). O valor médio obtido para a razão La/Yb foi de 18,83. Os padrões de 
elementos terras raras (ETRs) normalizados pelo condrito mostram variação leve, com enriquecimento leve a moderado em ETRs leves e padrão plano para os ETRs pesados. Todas as amostras possuem anomalias negativas de Eu pronunciadas, o que é consistente com o fracionamento dos feldspatos. Elementos menores e traço possuem trends que indicam a cristalização fracionada de plagioclásio, K-feldspato e biotita. Os dados de elementos traço forneceram evidências para determinar que o monzogranito Salininha é pós-colisional. Uma amostra representativa forneceu idade U-Pb (zircão), via abrasão química-diluição isotópica-espectrometria de massa de ionização térmica (CA-ID-TIMS), de $2003 \pm 4$ Ma, consistente com o plúton Salininha sendo intrusivo na porção sul do Bloco Gavião.

Palavras-chave: Bloco Gavião; Intrusão pós-tectônica; Monzogranito Salininha; Bahia; Brasil.

\section{INTRODUCTION}

The Proterozoic Eon is known by the abundant addition of granitic plutons along continental arcs, and their petrogenetic studies are a fundamental tool to understand the evolution of the continental crust (Kemp and Hawkesworth, 2003; Frost and Frost, 2013) and cratonic landmasses such as the São Francisco Craton (SFC) (Figure 1), now preserved within the South American Platform (Almeida, 1977).

Peraluminous high-silica igneous rocks rich in highfield strength elements (HFSE) have been under study for decades. The chemical and mineralogical characteristics of these rocks have been considered to reflect different source rocks and/or petrogenetic processes, mainly fractional crystallization. Their extremely felsic composition $\left(\mathrm{SiO}_{2}>71 \%\right)$ due to a long fractionation history makes discerning their magma sources and melting conditions difficult.

In this paper, we present new petrographic, whole rock major and trace elemental and geochronological (chemical abrasion-isotope dilution-thermal ionization mass

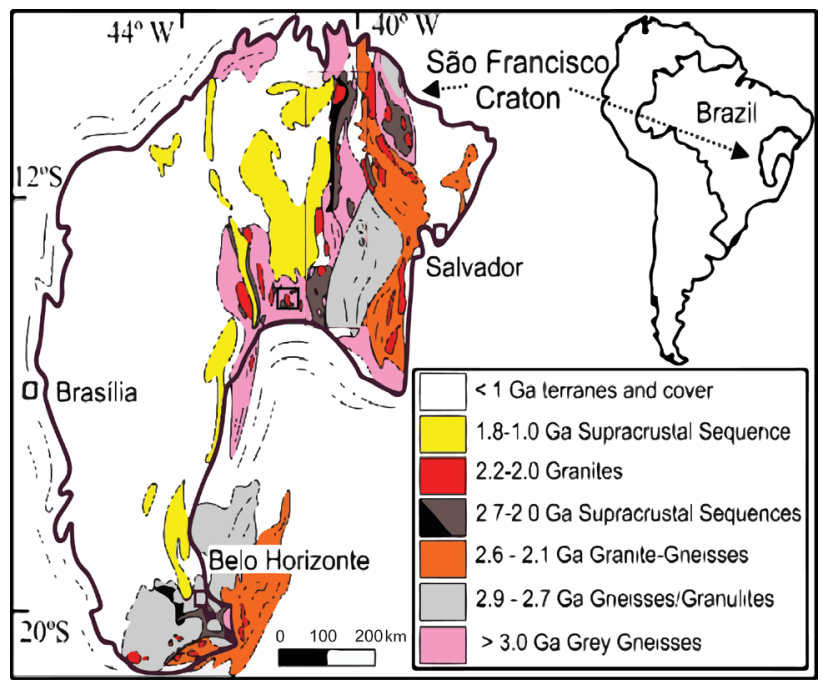

Source: modified from Zincone and Oliveira, 2017.

Figure 1. Location of the study area in the São Francisco Craton. spectrometry - CA-ID-TIMS zircon U-Pb) data of the Salininha monzogranite. This dataset allows us to characterize these granites and also helps us understand their petrogenesis and constraint on their tectonic setting.

\section{REGIONAL GEOLOGICAL SETTING}

The SFC represents a crustal block underlain by Archean components that was consolidated during the Paleoproterozoic, around 2.08 Ga (Barbosa and Barbosa, 2017). It contains rocks with ages ranging between 3.4 and $1.9 \mathrm{Ga}$ (Barbosa et al., 2012), which were not significantly affected by the deformation and metamorphism resulting from younger events, of Brasiliano age, during the Neoproterozoic (Barbosa and Sabaté, 2003; Cruz et al., 2016). The geological limits of the SFC are outlined by fold and thrust belts of Brasiliano age: the Sergipano Belt to the northeast; the Araçuaí and Ribeira Belts to the south; the Rio Preto and Riacho do Pontal Belts to the northwest; and the Brasília Belt to the west (Barbosa et al., 2009).

The study area is located in the central-western portion of SFC, within the Gavião Block (GB) (Figure 2). According to Barbosa and Sabaté (2003), this block is an ArcheanPaleoproterozoic crustal segment underlain by granitic gneisses and meta-volcano-sedimentary sequences, cut by acidic and basic intrusions (Barbosa et al., 2009; Brito, 2007). Superimposed to these units, there are metasedimentary rocks of Paleo/Meso- and Neoproterozoic age, represented by the Espinhaço and São Francisco supergroups (Palmeira, 2010).

\section{Gavião Block}

The studied area is located within the GB, which is predominantly comprised of orthogneisses, with other gneisses, tonalite-trondhjemite-granodiorite rocks (TTG), granulites, migmatites and amphibolites occurring in smaller amounts. Together, these rocks constitute what is known as the Gavião complex (Leal et al., 1998; Cruz et al., 2016), which contains portions of metavolcano-sedimentary sequences such as Caetité-Licínio de Almeida and Urandi 
and greenstone belts such as Riacho de Santana, Boquira, Guajeru, Umburanas, Brumado and Ibitira-Ubiraçaba (Silva and Cunha, 1999; Cunha et al., 2012). In the GB, Archean granitoid bodies are common, but granites such as Espírito Santo, Rio do Paulo, Caculé, Serra da Franga, Umburanas, Lagoa Real (Leal et al., 1998; Barbosa et al., 2012) and Salininha (the focus of this paper) represent Paleoproterozoic intrusions.

\section{Gavião complex and greenstone belts}

The Gavião complex (Figure 2) is, in general, composed of gray, fine- to medium-grained orthogneisses, and migmatites that have stromatic structure, and that, locally, shows agmatitic and schlieren structures. These rocks are extremely deformed and were metamorphosed at amphibolite facies during the Paleoproterozoic (around 2.08 Ga). Mafic enclaves (amphibolites) are common, occurring concordantly with the tectonic fabric of the enclosing

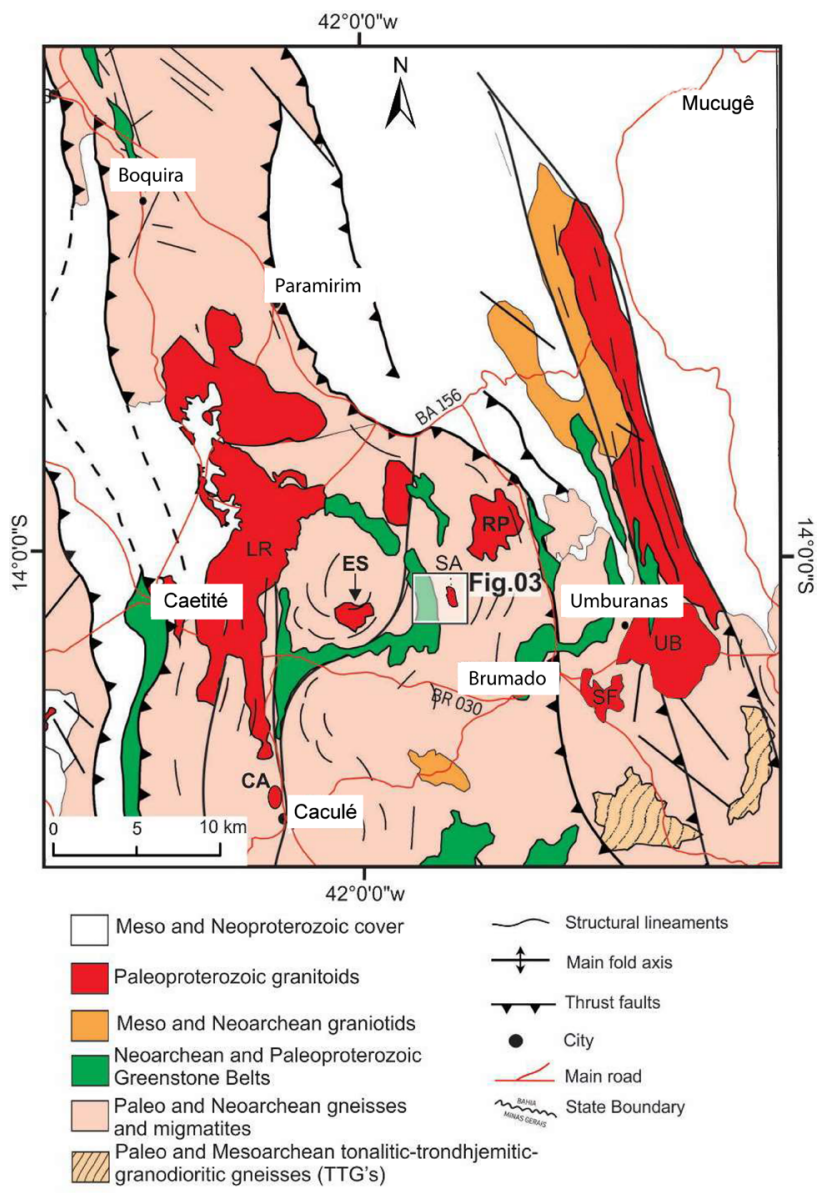

ES: Espírito Santo granite; RP: Rio do Paulo granite; CA: Caculé granite; SF: Serra da Franga granite; UB: Umburanas granite; LR: Lagoa Real granite; SA: Salininha granite.

Figure 2. Geological map of the southern portion of Gavião Block. orthogneisses. The oldest rocks of this complex are TTGs that have yielded Paleoarchean ages around 3.4-3.2 Ga (U-Pb sensitive high-resolution ion microprobe-SHRIMP on zircon) (Martin et al., 1997). However, the Gavião complex is dominated by Meso- to Neoarchean rocks with ages around 2.7 Ga (Arcanjo et al., 2005, Barbosa et al., 2012). Restricted exposures of granulitic rocks are also present in the Gavião Complex. They are greenish-gray and contain orthopyroxene, plagioclase, and quartz with lesser amounts of garnet, cordierite and kyanite.

With respect to the greenstone belts, Silva and Cunha (1999) and Cunha et al. (2012) argued that, despite uncertainties, these sequences have rocks of Archean ages at their base and Paleoproterozoic rocks on their middle and upper parts. The sequences comprise, in the base, mafic and ultramafic volcanic rocks, quartzites, calc-silicates, carbonates and iron formations, which then grade to sandy-clay sequences at the top. All of these rocks are deformed and metamorphosed at greenschist-to-amphibolite facies. Close to the study area, the Ibitira-Ubiraçaba greenstone belt exposes volcanic rocks, calc-silicates, iron formation, metapelites, quartzites, schists, amphibolites and serpentinites, cut by diabase sills. Granitic intrusions contour the semidomal structure of the Ibitira-Ubiraçaba greenstone belt (Arcanjo et al., 2005) (Figure 2).

\section{Paleoproterozoic granitoids}

The Gavião Block is intruded by granitoids interpreted to be of Paleoproterozoic age (Santos-Pinto et al., 2012) such as Salininha monzogranite, Espírito Santo, Rio do Paulo, Caculé, Serra da Franga and Umburanas (Figure 2).

Espírito Santo occurs to the northwest of the city of Brumado and is homogeneous in appearance. It is fineto-medium grained and it has slightly foliated structure. Enclaves of rocks from the Gavião Complex are found within this pluton. It shows granoblastic texture, with disseminated biotite $(\sim 4 \%)$ and an irregular mosaic of microcline $(\sim 55 \%)$, plagioclase $(\sim 20 \%)$ and quartz $(\sim 20 \%)$. Muscovite $(\sim 1 \%)$ also occurs and it is almost always associated with biotite. Apatite, monazite and zircon represent the main accessory phases. Analyses of zircon using the $\mathrm{Pb}$ evaporation method yielded a ${ }^{207} \mathrm{~Pb} /{ }^{206} \mathrm{~Pb}$ crystallization age of $2012 \pm 25 \mathrm{Ma}$, while $\mathrm{Sm}-\mathrm{Nd} \mathrm{T}_{\mathrm{DM}}$ model ages ranged between 3.05 and $3.09 \mathrm{Ga}$. The initial $\varepsilon_{\mathrm{Nd}(t)}$ clustered between -11.0 and -12.0 , indicating a crustal origin (Leal et al., 2000).

The Rio do Paulo granitoid is located to the northwest of the city of Brumado, and intruded both the TTG terranes and the metavolcano-sedimentary rocks of Brumado greenstone belt. This massif comprises relatively homogeneous rocks that are coarse grained and are represented, 
essentially, by biotite granites and hornblende-biotite granites, which are strongly foliated by shear tectonics and locally show augen-type structures. The typical mineral composition of the Rio do Paulo intrusion includes microcline $(10 \%)$ and quartz (20\%) porphyroclasts immersed in a fine matrix of plagioclase, quartz and microcline (this matrix represents approximately $35 \%$ of the rock's volume). Biotite $(\sim 20 \%)$ and hornblende $(\sim 15 \%)$ occur randomly while opaques, zircon, titanite, monazite and apatite constitute the accessory mineralogy. Isotopic data indicated a Rb-Sr (errorchron) age of $1959 \pm 50 \mathrm{Ma}$ $(\mathrm{MSWD}=9.2)$ with an elevated initial ${ }^{87} \mathrm{Sr} /{ }^{86} \mathrm{Sr}$ ratio $=$ $0.71084 \pm 0.00176$, as well as a Sm-Nd $\mathrm{T}_{\mathrm{DM}}$ model age $=$ $2.73 \mathrm{Ga}$ and initial $\varepsilon_{\mathrm{Nd}(\mathrm{t})}=-6.1$, indicating crustal origin (Leal et al., 1998).

The Caculé granitoid is located near the homonymous town, and it has a homogeneous appearance, but discrete orientation of its mafic components (amphibole and biotite), scattered in a mosaic made up of quartz and plagioclase. Its rocks show strong foliation with a local mylonitic aspect. Angular xenoliths of paragneisses from the GB also occur. In areas of low strain, it exhibits a granoblastic texture with crystals of microcline $(\sim 35 \%)$, plagioclase $(\sim 30 \%)$ and quartz $(\sim 20 \%)$, together in polygonal aggregates, while biotite $(\sim 9 \%)$ occurs as irregular blades associated with hornblende $(\sim 5 \%)$ and allanite $(\sim 1 \%)$ crystals. Opaque minerals, titanite, allanite and irregular masses of apatite are commonly associated with biotite and amphibole. Fine crystals of apatite and zircon, frequently included in feldspars, comprise the dominant accessory assemblage. $\mathrm{Six}$ zircon grains analyzed by the $\mathrm{Pb}$ evaporation method yielded a mean ${ }^{207} \mathrm{~Pb} / 206 \mathrm{~Pb}$ age of $2019 \pm 32 \mathrm{Ma}$, interpreted to represent the age of the igneous crystallization (Leal et al., 2000). Two samples provided Sm-Nd $\mathrm{T}_{\mathrm{DM}}$ model ages of 2.63 and $2.74 \mathrm{Ga}$ and initial $\varepsilon_{\mathrm{Nd}(t)}$ values of -6.8 and -7.9 , together with elevated initial ${ }^{87} \mathrm{Sr} /{ }^{86} \mathrm{Sr}$ isotopic ratios (0.704 to 0.710 ), which document a significant crustal component within these granitoids' magmas (Leal et al., 1998).

The Serra da Franga granitoid lies to the southeast of the city of Brumado, and it is isotropic and fine-grained. It is composed of quartz, plagioclase, potassic feldspar, biotite, titanite, opaque minerals, zircon and apatite, having epidote, muscovite and minor carbonate of hydrothermal origin as alteration minerals (Barbosa et al., 2012). Its age, $2039 \pm 11$ Ma (Santos-Pinto, 1996; Santos-Pinto et al., 1998), was determined by zircon evaporation.

The Umburanas granitoid outcrops along a railway bed that links the cities of Brumado and Tanhaçu. This igneous body can be classified as a porphyritic biotite-granodiorite (Barbosa et al., 2012). According to Barbosa et al. (2012), this rock exhibits phenocrysts of microcline and plagioclase dispersed in a matrix of quartz, plagioclase, microcline, biotite, apatite, zircon and monazite, with epidote, muscovite and sericite as secondary minerals. Geochronological data obtained by zircon evaporation revealed ages that range from 3.13 to $2.5 \mathrm{Ga}$, with inherited cores (Santos-Pinto, 1996; Santos-Pinto et al., 1998). However, a Pb evaporation age ( $\mathrm{Pb}-\mathrm{Pb}$ method) was determined on monazite that yielded the age of $2049 \pm 6 \mathrm{Ma}$, interpreted to represent the crystallization age of the granitoid. Tracer isotopic data showed highly negative values for initial $\varepsilon_{\mathrm{Nd}}(-14)$ and an elevated ${ }^{86} \mathrm{Sr} /{ }^{87} \mathrm{Sr}$ initial ratio, at $2.05 \mathrm{Ga}$, ranging between 0.730 and 0.752 , which suggests that this rock derives largely from older crustal materials (Santos-Pinto et al., 1998).

The Lagoa Real granitoid is located to the southeast of Brumado and comprises different types of felsic rocks, such as metagranitoids, mylonitized granitoids, albitites and microcline-rich rocks. The metagranitoids are constituted by K-feldspar, plagioclase and biotite. The albitites are composed by more than $70 \%$ of albite, while the microcline-rich rocks are pink and are constituted by more than $70 \%$ of microcline. These rocks are of Paleoproterozoic age $(1.7 \mathrm{Ga})$, according to Turpin et al. (1988) and Cruz and Alkmim (2007). However, they have been intensely deformed during the Neoproterozoic.

\section{Geotectonic evolution}

In relation to the geotectonic models created for the Archean-Paleoproterozoic of the GB, according to Barbosa and Sabaté $(2002,2004)$, the four Archean blocks Gavião (GB), Jequié (JB), Serrinha (SB) and ItabunaSalvador-Curaçá (ISCB) (Figure 1) - collided in the Paleoproterozoic, with deformation and peak metamorphism culminating between $2.1-2.0 \mathrm{Ga}$. This collision made the ISCB override the JB and the JB override the GB, generating, over the last, a penetrative deformation and granulite-to-amphibolite facies metamorphism, which locally migmatized the oldest rocks of the Gavião complex, and the greenstone belts. In a late crustal relaxation stage, numerous post-tectonic granitic bodies intruded the GB, such as the Salininha monzogranite.

\section{ANALYTICAL METHODS}

In this study, nine samples were collected, but a total of eight (seven from the Salininha monzogranite and one from the orthogneisses of the Gavião Complex), with least alteration, was analyzed for major oxides and trace elements. One sample (SL-06A) was also analyzed for CA-ID-TIMS $\mathrm{U}-\mathrm{Pb}$ geochronology.

Loss on ignition (LOI) was determined by calcinating the samples for 2 hours at $900^{\circ} \mathrm{C}$ at an electric furnace. 
Whole rock powders were prepared and subjected to a lithium tetraborate fusion, followed by analysis for major (and selected trace) elements by inductively coupled plasma (ICP) (Thermo Jarrell Ash ENVIRO II ICP or Varian Vista 735 ICP) and, for most of the trace elements, using an ICP-MS (Perkin Elmer Sciex ELAN 6.000, 6.100 or 9.000 mass spectrometer). All lithogeochemical analyses were conducted by Activation Laboratories (Actlabs), located in Ancaster, Ontario, Canada.

Zircon grains were treated by the chemical abrasion method (CA). They were annealed in quartz crucibles at $1,000^{\circ} \mathrm{C}$ for forty-eight hours. After this period, the grains were leached in a 1:1 mixture of concentrated $\mathrm{HF}$ and $6 \mathrm{~N} \mathrm{HCl}$ for several hours in a Teflon bomb at $195^{\circ} \mathrm{C}$. Selected etched single grains were dissolved completely in a mixture of ultrapure $\mathrm{HF} / \mathrm{HNO} 3$ acids to which was added a mixed $205 \mathrm{~Pb}-235 \mathrm{U}$ isotopic tracer, in Teflon bombs at $195^{\circ} \mathrm{C}$ over a span of three days. $\mathrm{U}$ and $\mathrm{Pb}$ were isolated via ion exchange column chemistry, loaded directly on outgassed Re filaments, and analyzed on a VG354 mass spectrometer using digital ion counting with a daly photomultiplier detector at the Jack Satterly Geochronology Laboratory at the University of Toronto, Canada.

\section{RESULTS}

The GB, as shown in Figures 1 and 2, preserves both syn-tectonic granites such as the Rio do Paulo intrusion, as well as

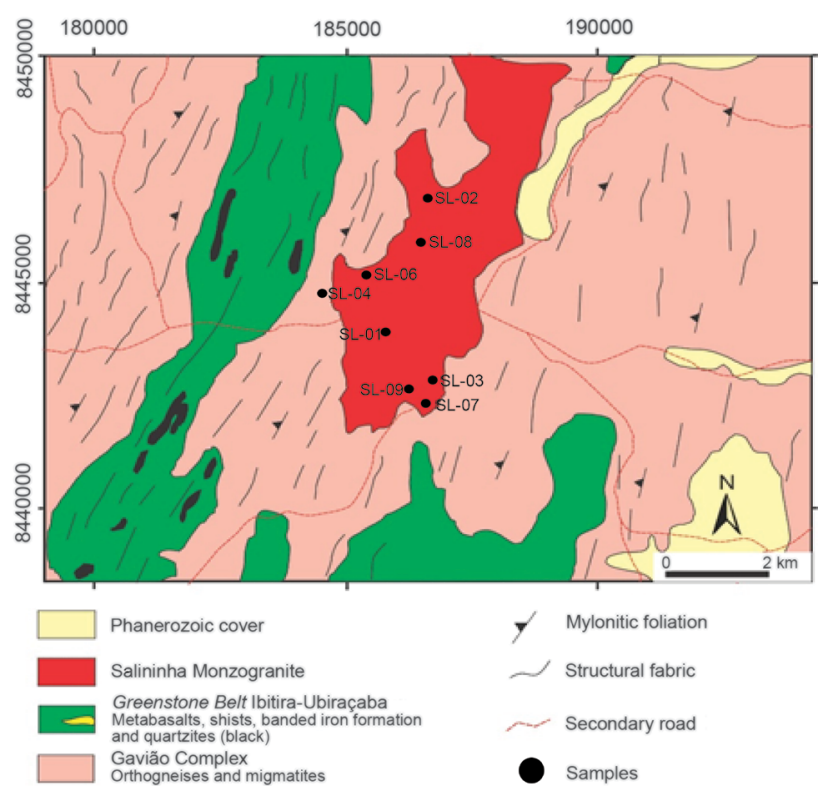

Figure 3. Simplified geological map of the study area, with emphasis on the Salininha monzogranite. post-tectonic granitoids such as Caculé and Espírito Santo. The syn-tectonic granites show penetrative foliations, whereas in the post-orogenic plutons deformation fabrics are practically absent. Once the Salininha pluton intrudes the Gavião Complex and it is undeformed, it represents the post-tectonic granites. Figure 3 shows a geological map of the Salininha intrusion and its relationship to the enclosing rocks of the Gavião Complex.

\section{Field relations and petrography}

The host rocks of the Salininha monzogranite are the orthogneisses of Gavião complex that are Archean in age (2.7 Ga) (Barbosa et al., 2012), but were deformed and reequilibrated in the Paleoproterozoic. The contact between the Gavião complex and the Salininha pluton is generally sharp and abrupt, as illustrated in Figure 4A. The orthogneisses are characterized by the occurrence of leucocratic and melanocratic layers (Figure 4B). The leucocratic ones are essentially composed by quartzo-feldspathic minerals, while the melanocratic parts are formed by ferromagnesian minerals such as biotite and rare amphiboles.
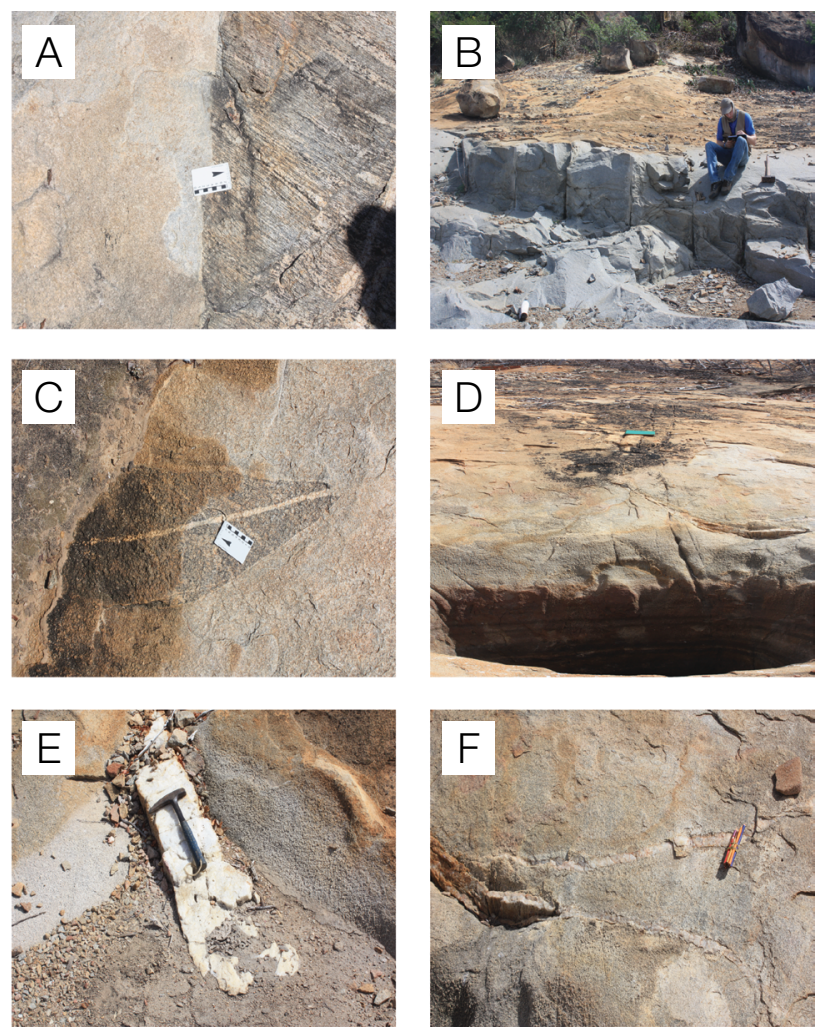

Figure 4. Outcrop photos. (A) Contact between Salininha monzogranite and the Gavião orthogneiss. (B) Quarry outcrop of Salininha monzogranite. (C) Enclaves of the orthogneiss in the monzogranite. (D) Fractures in the monzogranite. $(E)$ and $(F)$ Quartz veins. 
Macroscopically, these rocks are equigranular, medium grained and have approximately the equal proportions of quartz, plagioclase and K-feldspar.

The outcrops of Salininha monzogranite are scarce and occur, predominantly, as flat blocks, although two of them form small hills from where rocks for construction are extracted by the local population (Figure 4B). Rock color varies from light to dark grey, when not altered, and from ochre to whitish, when altered. It is an isotropic, massive rock that sometimes shows incipient foliation developed on the pluton margins, probably due to its mechanical interaction with the enclosing rock during emplacement, presumably as a crystal-laden mush. Xenoliths of the Gavião Complex are locally found in the granitoid (Figure 4C). Quartz veins are not uncommon within the intrusion filling fractured zones (Figures 4D, 4E and 4F).

During fieldwork, eight samples of the Salininha granitoid (SL-01, SL-02, SL-05, SL-06A, SL-07, SL-08, SL-03 and SL-09) and one of the orthogneiss (SL-04) were collected (Figure 3). Petrographic microscopy confirmed that the intrusive rocks are essentially inequigranular hypdiomorphic, with medium-to-coarse phaneritic texture. Table 1 summarizes the modal compositions of the samples from the Salininha pluton.

The mineralogy of this intrusion mainly comprises quartz, plagioclase, K-feldspar, biotite (Figure 5A) and muscovite (Figure 5B). Hornblende, epidote, opaques and zircon occur as accessory phases. Quartz represents 27 to $35 \%$ of the rock's total volume, with predominantly subhedral grains, its size varying from 0.7 to $1.0 \mathrm{~cm}$. Quartz shows no preferred orientation in most samples. The observed plagioclase (albite), obtained via MichelLevy Method (extinction angle of the lamellae) represents 15 to $32 \%$ of the modal volume and it is present mostly as subhedral grains with albite twinning. Its grain size varies from 0.4 to $1.0 \mathrm{~cm}$. K-feldspar comprises 18 to $28 \%$ of the mode, present as mostly subhedral grains, with size ranging between 0.3 and $1.5 \mathrm{~cm}$. Brown biotite constitutes 9 to $20 \%$ of the rock with maximum grain size between 0.5 and $2.0 \mathrm{~cm}$. It has straight boundaries with other grains and against each other. Hydrothermal alteration of biotite to green chlorite and muscovite was observed in the samples (Figures 5A-5D). Most of the samples contain greenish-black, prismatic hornblende, without preferred orientation, but it represents only between 2 to $4 \%$ of the volume. Hornblende grain size varies between 0.3 and 0.7 $\mathrm{cm}$ and it is, sometimes, turning into chlorite (Figure 5E). There is also sericite present as product of the alteration of the plagioclase (Figure 5F). Zircon is a nearly ubiquitous accessory phase $(\sim 1 \%)$, typically as small grains ( $\sim 300$ microns), readily identified by its high relief and pleochroic halos when included in biotite. Along with biotite, muscovite is always present at between $3-5 \%$ of the mode. Opaque minerals are present only at the trace level $(1 \%)$, and also is epidote $(1 \%)$ identified in four samples. Based on petrographic observations, a proposed crystallization sequence for the studied samples may be: opaques-zircon-biotite-andesine-microcline-quartz-epidote.

The photomicrograph of Figure 5G shows biotite rich bands. In turn, the photomicrograph of Figure $5 \mathrm{H}$ also shows, on thin section, the abrupt contact between Salininha monzogranite and Gavião orthogneiss (Figure 4B).

From the modal values, obtained via the analysis of 15 fields on each one of the studied polished thin sections (Table 1), it was possible to classify the Salininha samples in terms of the QAP scheme (Streckeisen, 1976) (Figure 6). With nearly subequal proportions of all principal mineral phases, all of the samples plot entirely within the monzogranite field.

\section{Lithogeochemistry}

Field and petrographic studies reveal that the Salininha pluton was not deformed. It was possible to observe that some alteration took place in these rocks since biotite had

Table 1. Modal composition of the Salininha monzogranite and its enclosing rock.

\begin{tabular}{lccccccccc}
\hline Minerals (modal \%) & SL-01 & SL-02 & SL-05 & SL-06A & SL-07 & SL-08 & SL-03 & SL-09 & SL-04 \\
\hline Quartz & 30 & 30 & 32 & 30 & 30 & 27 & 28 & 35 & 30 \\
Plagioclase & 25 & 32 & 20 & 25 & 26 & 20 & 22 & 23 & 15 \\
K-Feldspar & 26 & 18 & 26 & 22 & 21 & 28 & 24 & 18 & 25 \\
Biotite & 9 & 10 & 11 & 11 & 10 & 12 & 12 & 11 & 20 \\
Hornblende & 3 & & & 2 & 3 & 2 & 3 & 2 & 4 \\
Muscovite & 5 & 5 & 5 & 4 & 4 & 5 & 5 & 5 & 3 \\
Chlorite & & 3 & 3 & 3 & 3 & 3 & 3 & 3 & 1 \\
Zircon & 1 & 1 & 1 & 1 & 1 & 1 & 1 & 1 \\
Epidote & 1 & 1 & 1 & 1 & 1 & 1 & 1 & 1 & 1 \\
Opaques & 1 & 1 & 1 & 1 & 1 & 1 \\
\hline
\end{tabular}


turn into chlorite and the plagioclase was being transformed into sericite.

The granites' samples have high $\mathrm{SiO}_{2}$ content (71.56-75.00 wt.\%) (Table 2). They are slightly peraluminous
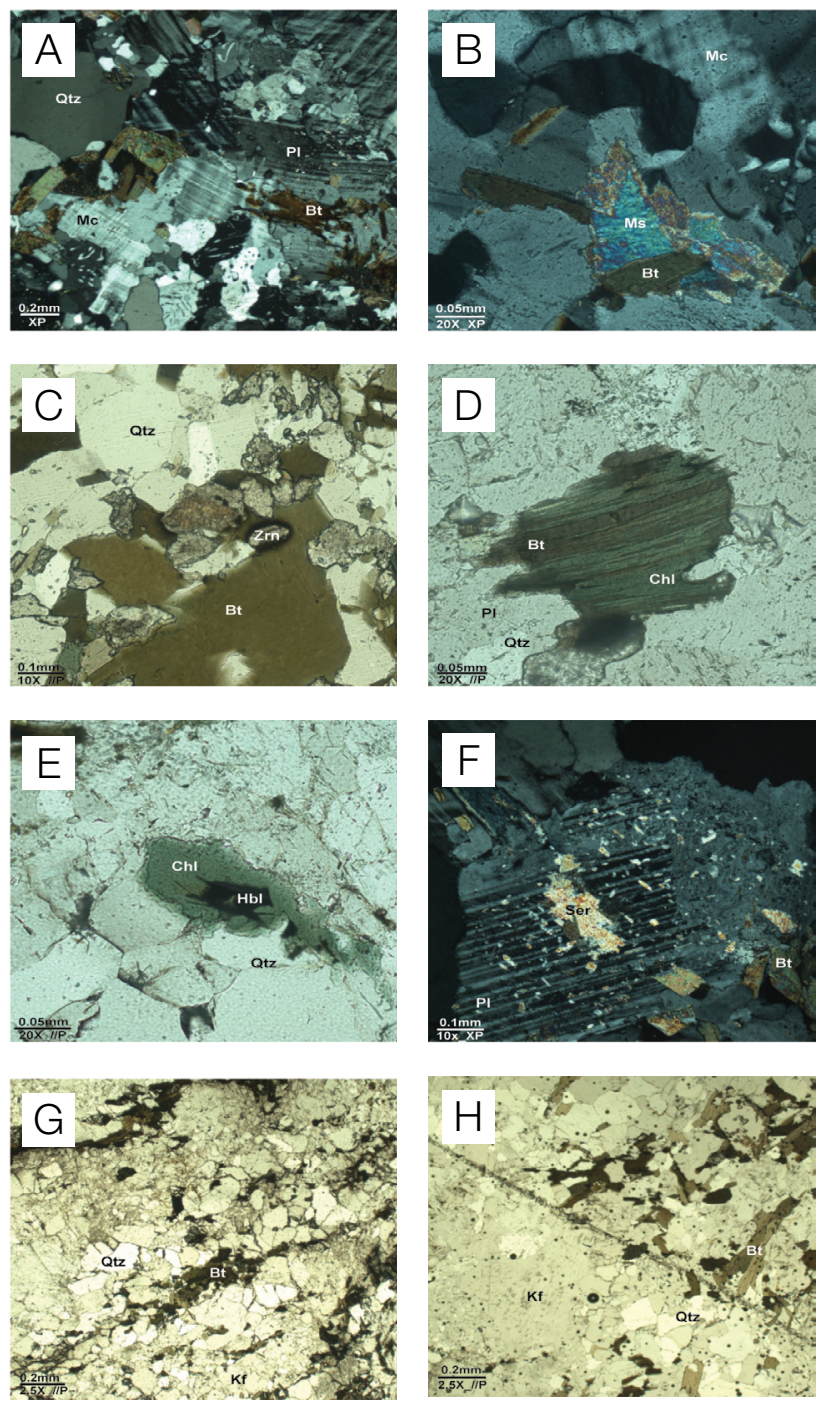

XP: crossed nicols; //P: parallel nicols; Qtz: quartz; Mc: microcline; Pl: plagioclase; Bt: biotite; Ms: muscovite; Chl: chlorite; Ser: sericite; Kf: potassic feldspar.

Figure 5. Microscopic features of the Salininha monzogranite. (A) Overview of the monzogranite's mineralogy. (B) Biotite and muscovite that characterize the monzogranite. (C) Zircon (Zrn) inside the biotite exhibiting pleochroic halos. (D) Biotite altering to chlorite. (E) Hornblende ( $\mathrm{Hbl}$ ) altering to chlorite. (F) Plagioclase altered to white mica. (G) Concentration of biotite in bands, in the monzogranite. $(H)$ Abrupt contact between the monzogranite (bottom left) and Gavião orthogneiss (upper right). Abbreviations of the minerals' names according to Whitney and Evans (2010). with $\mathrm{A} / \mathrm{CNK}$ ratios $\left[\right.$ modal $\mathrm{Al}_{2} \mathrm{O}_{3} /\left(\mathrm{CaO}+\mathrm{Na}_{2} \mathrm{O}+\mathrm{K}_{2} \mathrm{O}\right)$ ] of $1.00-1.10$, whereas their enclosing rock is metaluminous with alumina saturation index (ASI) of 0.93 (Figure 7A) (Shand, 1943). According to the classification of Frost et al. (2001), all granitic samples plot in the ferroan field, with $\mathrm{FeOt} /(\mathrm{FeOt}+\mathrm{MgO})$ ratios between 0.84 and 0.92 (Figure 7B) and in the alkali-calcic field in the $\left(\mathrm{Na}_{2} \mathrm{O}+\mathrm{K}_{2} \mathrm{O}-\right.$ $\mathrm{CaO}$ ) versus $\mathrm{SiO}_{2}$ diagram, while the host rock sample plots in the calc-alkalic field of the same diagram (Figure 7C). These data indicate that the granites under study are roughly similar to the peraluminous A-type granites.

All samples (from the monzogranite and its enclosing rock) show chondrite-normalized rare earth element (REE) patterns (Boynton, 1984), with a relative enrichment of light rare earth elements (LREEs) and flat-to-steep heavy rare earth elements (HREEs) with negative Eu anomalies $\left(\mathrm{Eu} / \mathrm{Eu}^{*}=0.17-0.37\right)$ (Figure $\left.8 \mathrm{~A}\right)$. These negative Eu anomalies indicate the fractional crystallization of the feldspars. These granitic rocks show wide variation relative to the REE abundance $\left(\sum \mathrm{REE}=237.68-795.56\right.$ $\mathrm{ppm}$ ), whereas the host rock has $\sum \mathrm{REE}=1,032.18 \mathrm{ppm}$. The REE patterns are highly to moderately fractionated, with $(\mathrm{La} / \mathrm{Yb}) \mathrm{N}$ varying from 4.54 to 66.51 . In the primitive mantle-normalized trace element diagram (Figure 8B) (McDonough and Sun, 1995), all the samples are depleted in high field strength elements (HFSEs) such as $\mathrm{Nb}, \mathrm{Sr}$ and $\mathrm{Ti}$ and enriched in $\mathrm{P}$. These pronounced negative anomalies for $\mathrm{Ba}, \mathrm{Sr}$ and $\mathrm{Ti}$ are possibly related to the fractional crystallization of feldspar and titanium and iron oxides. Sample RB-03 shows a different REE pattern, which is probably related to the influence of the host rock. In the Harker (1909) diagrams (Figure 9), and the representative

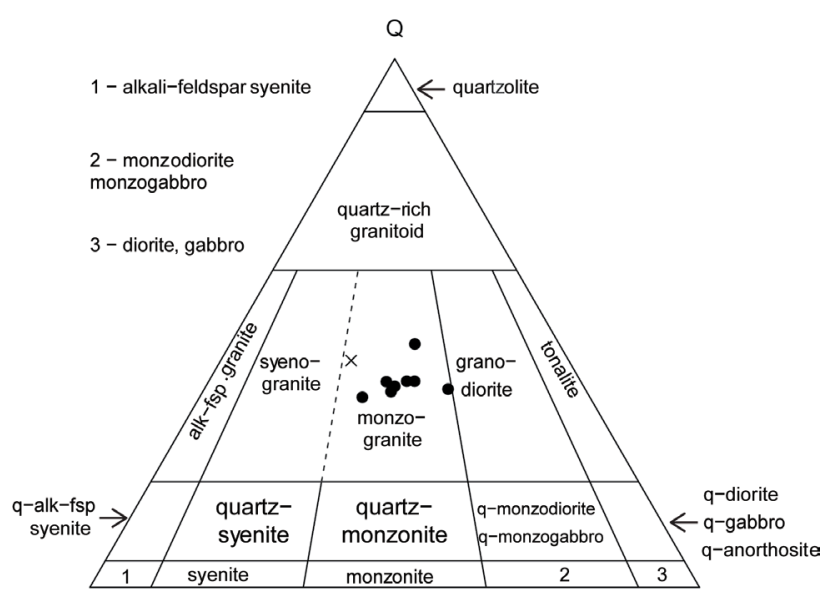

Q-alk-fsp: quartz alkali-feldspar; alk-fsp: alkali-feldspar.

Figure 6. Ternary diagram (Streckeisen, 1976) with the classification of Salininha monzogranite. The black dots represent the studied samples. The $X$ represents the sample from the country rock. 
points of the chemical analysis of the granites' samples are disperse. However, it is possible to verify that these monzogranites exhibit positive correlations between $\mathrm{SiO}_{2}$ and $\mathrm{Al}_{2} \mathrm{O}_{3}$, and $\mathrm{SiO}_{2}$ and $\mathrm{Na}_{2} \mathrm{O}$ do not show strong variations between $\mathrm{SiO}_{2}$ and $\mathrm{FeOt}$ and $\mathrm{TiO}_{2}$. Table 3 presents the chemical compositions of Salininha monzogranite and its host rock in terms of trace and REE.

\section{Geochronology}

Zircons were separated from one of the monzogranite samples from the central western part of the Salininha pluton (sample SL-06A) (Table 4). Most zircon morphologies in this sample are square, doubly-terminated prisms, but they are metamict due to radiation resulting in high $\mathrm{U}$ concentrations (Figures 10A, 10B and 10C). Chemical abrasion of these grains resulted in only fragile residues (shells) available for dissolution and analysis. ID-TIMS analysis of eight selected single grain zircon fractions was done at the University of Toronto. The resulting distribution of the data is shown in Figure 11. Although the data are highly discordant, for the most part they are generally collinear. Exceptions to this include fraction Z4, which has a distinctly higher $\mathrm{Th} / \mathrm{U}$ ratio [0.35] than most analyses [mostly $<0.10$ ]; fraction $\mathrm{Z} 4$ has a model ${ }^{207} \mathrm{~Pb} /{ }^{206} \mathrm{~Pb}$ age of $2311 \mathrm{Ma}$ and it is clearly xenocrystic in origin. Fraction $Z 1$ falls to the right of a regression that includes all other analyses; this fraction is characterized by a higher $\mathrm{Th} / \mathrm{U}$ ratio [0.22] and likely also reflects inheritance. Most other fractions have ${ }^{207} \mathrm{~Pb} /{ }^{206} \mathrm{~Pb}$ ages $<2000 \mathrm{Ma}$, and the best subset, comprised of Z5, Z6 and Z7 regress to yield an upper intercept age of $2003 \pm 4 \mathrm{Ma}$ (probability of fit $=87 \%$ ) (Figure 12, inset, lower right). This age represents the best estimate of the age of emplacement and crystallization of the Salininha

Table 2. Major element chemical compositions of Salininha monzogranite and its enclosing rock.

\begin{tabular}{ccccccccc}
\hline & SL-01 & SL-02 & SL-06A & SL-07 & SL-08 & SL-03 & SL-09 & SL-04 \\
\hline $\mathrm{SiO}_{2}$ & 73.96 & 74.43 & 73.22 & 73.55 & 72.78 & 71.56 & 75.00 & 74.21 \\
$\mathrm{Al}_{2} \mathrm{O}_{3}$ & 13.62 & 13.71 & 13.17 & 13.44 & 13.03 & 13.42 & 13.85 & 11.81 \\
$\mathrm{FeO}(\mathrm{t})$ & 2.09 & 2.02 & 1.68 & 2.04 & 1.91 & 2.36 & 1.29 & 4.22 \\
$\mathrm{MnO}$ & 0.03 & 0.03 & 0.03 & 0.04 & 0.03 & 0.04 & 0.03 & 0.05 \\
$\mathrm{MgO}$ & 0.27 & 0.28 & 0.25 & 0.26 & 0.26 & 0.42 & 0.17 & 0.35 \\
$\mathrm{CaO}$ & 1.12 & 0.81 & 0.90 & 0.97 & 1.09 & 0.8 & 0.63 & 1.38 \\
$\mathrm{Na}_{2} \mathrm{O}$ & 3.27 & 3.63 & 3.46 & 3.49 & 3.17 & 3.39 & 3.61 & 2.76 \\
$\mathrm{~K}_{2} \mathrm{O}$ & 5.11 & 5.53 & 4.96 & 5.13 & 5.37 & 5.39 & 5.06 & 5.20 \\
$\mathrm{TiO}_{2}$ & 0.16 & 0.17 & 0.14 & 0.15 & 0.14 & 0.24 & 0.12 & 0.46 \\
$\mathrm{P}_{2} \mathrm{O}_{5}$ & 0.06 & 0.05 & 0.04 & 0.06 & 0.06 & 0.06 & 0.04 & 0.07 \\
$\mathrm{LOI}_{\mathrm{Total}}$ & 0.98 & 0.29 & 0.42 & 0.68 & 3.14 & 0.97 & 0.66 & 0.27 \\
$\mathrm{~T}$ & 100.67 & 100.95 & 98.27 & 99.80 & 100.98 & 98.65 & 100.50 & 100.78 \\
\hline
\end{tabular}
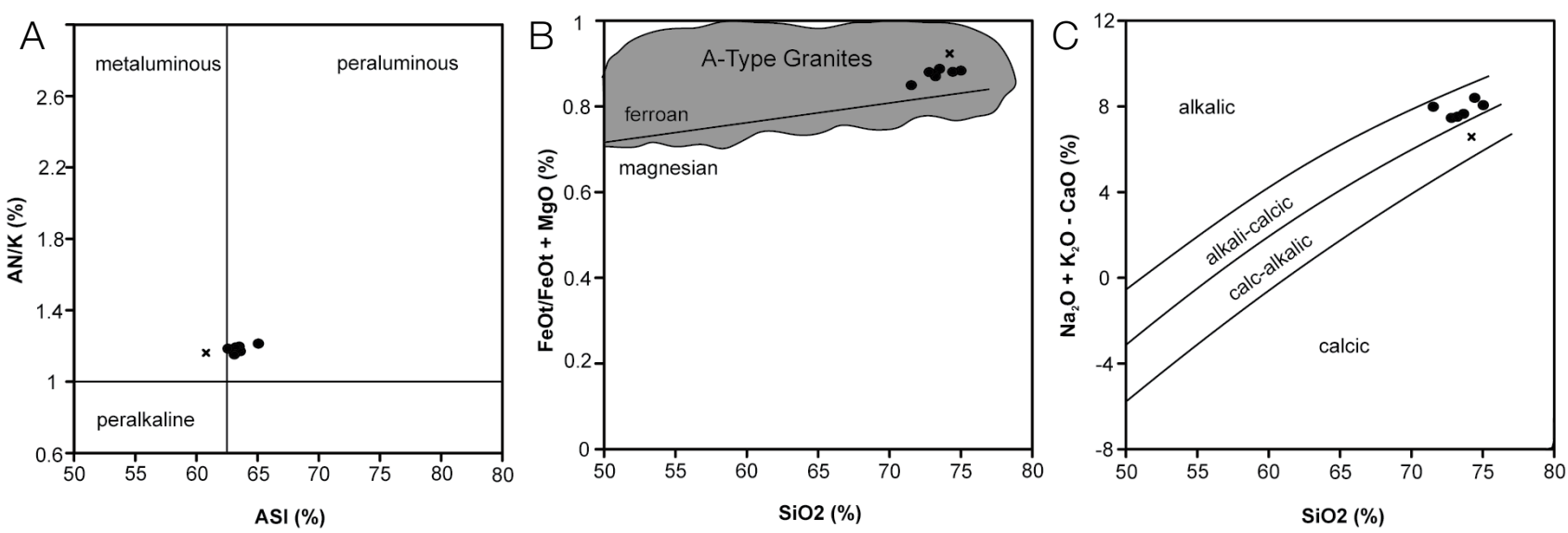

Figure 7. (A) A/CNK vs. A/NK diagram (after Shand, 1943) showing chemical composition of the Salininha monzogranite (black circles) and of the Gavião orthogneiss $(\mathrm{X})$ in terms of alumina saturation. (B) $\mathrm{Fe}^{*}[\mathrm{FeOt} /(\mathrm{FeOt}+\mathrm{MgO})]$ vs. $\mathrm{SiO}$. (C) MALI-index $\left(\mathrm{Na}_{2} \mathrm{O}+\mathrm{K}_{2} \mathrm{O}-\mathrm{CaO}\right)$ vs. $\mathrm{SiO}_{2}$ diagrams (after Frost et al., 2001). 
monzogranite. The low $\mathrm{Th} / \mathrm{U}$ values $[0.05-0.09]$ in the magmatic population are consistent with zircon crystallizing from crustal partial melt.

The regression described yields a lower intercept that is roughly of early Paleozoic age ( $420 \mathrm{Ma})$. This value is younger than expected for late Neoproterozoic (e.g., Brasiliano orogeny) thermal effects to be responsible for a superimposed $\mathrm{Pb}$-loss event. Nonetheless, the dispersion likely reflects the combined behaviour of secondary Pb-loss during that time, integrated with more recent $\mathrm{Pb}$-loss related to uplift.

\section{DISCUSSION AND CONCLUSIONS}

\section{A-type affinity of Salininha monzogranite}

All samples of the Salininha monzogranite plot in the A-type field of the $\mathrm{FeO}^{*} v s . \mathrm{SiO}_{2}$ diagram of Frost et al. (2001)
(Figure 7B). Whalen et al. (1987) proposed different discrimination diagrams to separate A-type granites from the other types (I and S). According to the parameters of these authors, all the samples of the Salininha pluton plot in the A-type field of the $\mathrm{Ce}, \mathrm{Y}$ and $\mathrm{Nb} v$ s. $10,000 * \mathrm{Ga} / \mathrm{Al}$ diagrams (Figures 12A, 12B and 12C).

\section{Tectonic setting of the Salininha monzogranite: anorogenic or post-collisional?}

A-type granites were first considered as anorogenic (Loiselle and Wones, 1979), but later studies questioned this consideration. Authors such as Whalen et al. (1987) and Eby (1992) pointed out that these granites could be either anorogenic or post-tectonic. According to Eby (1992), the A-types can be subdivided into A1 and A2. Based on these parameters, $\mathrm{A} 1$ granites $(\mathrm{Y} / \mathrm{Nb}<1.2)$ are considered to be emplaced at anorogenic settings, and A2 granites $(\mathrm{Y} / \mathrm{Nb}>1.2)$ are considered to be emplaced in
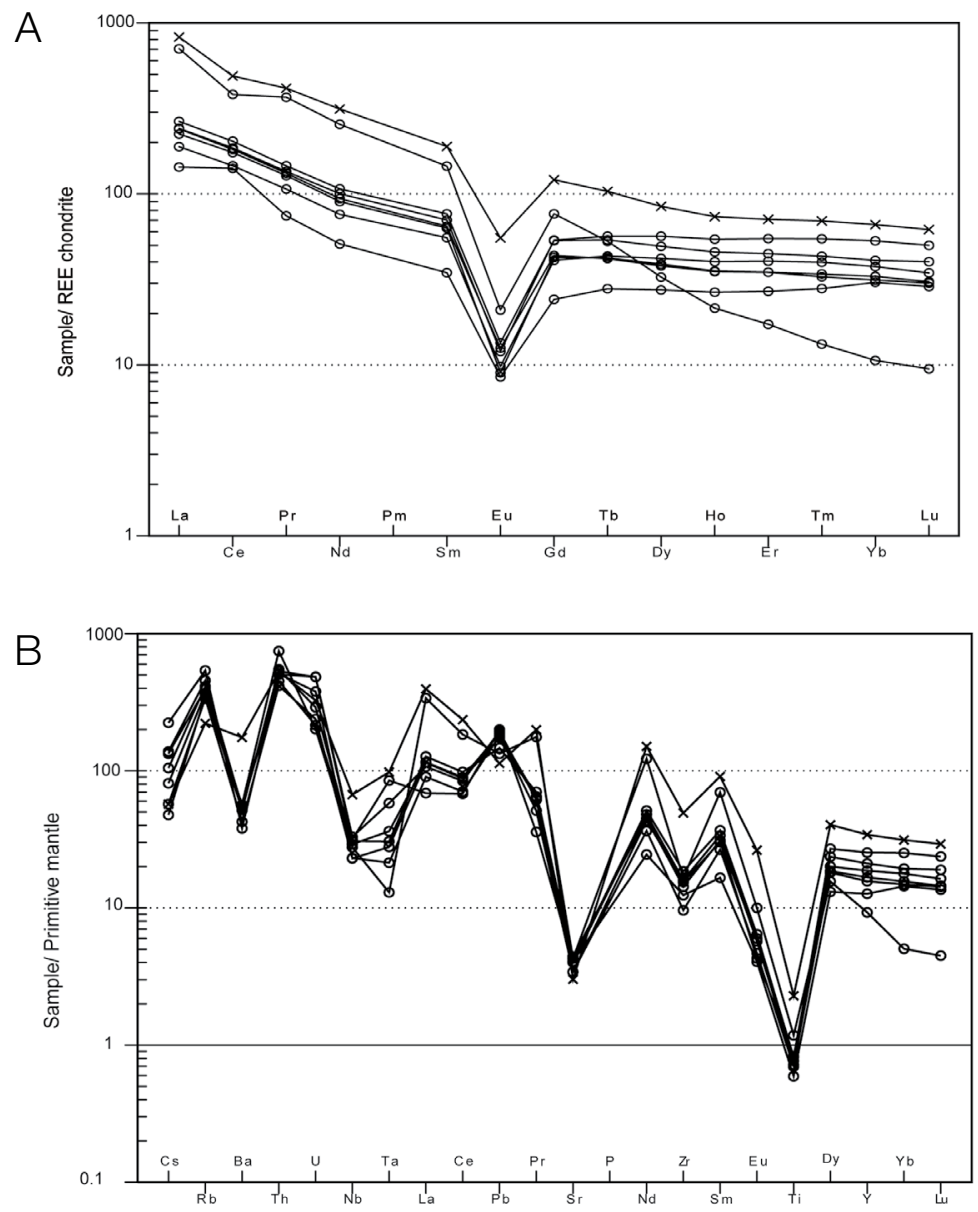

Figure 8. (A) Chondrite-normalized rare earth elements (REE) patterns for the monzogranite (circles) and for the Gavião Orthogneiss $(\mathrm{X})$. (B) Primitive mantle-normalized trace element patterns for the monzogranite and for the Gavião orthogneiss (symbols as in letter a). 

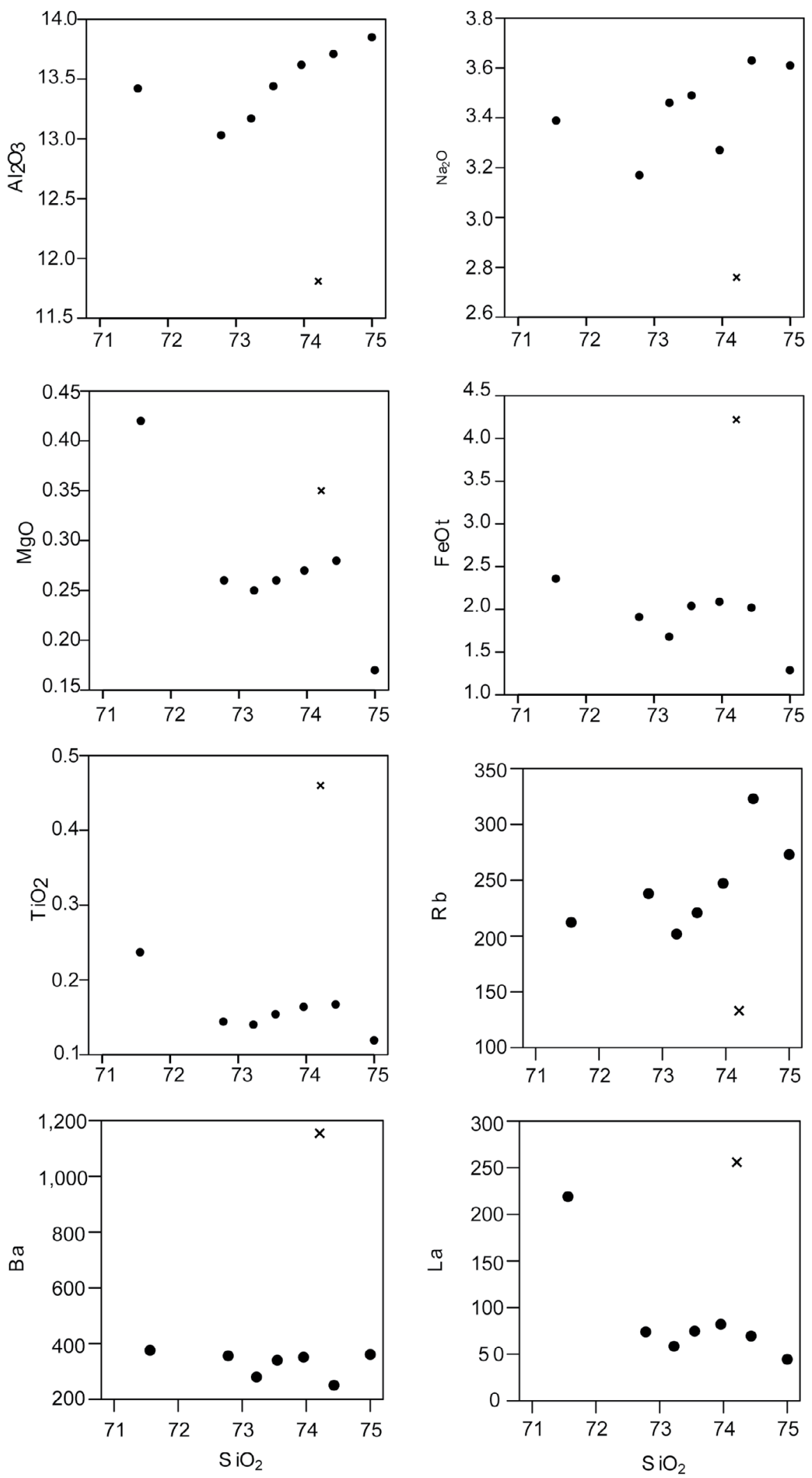

Figure 9. Harker (1909) for major and trace elements for Salininha monzogranite (black circles) and Gavião orthogneiss $(04-\mathrm{X}) .03$ and 09 represent the maximum and minimum contents of $\mathrm{SiO}_{2}$ for the granite. 
Table 3. Trace and rare earth element (REE) chemical compositions of Salininha monzogranite and its enclosing rock.

\begin{tabular}{ccccccccc}
\hline & SL-01 & SL-02 & SL-06A & SL-07 & SL-08 & SL-03 & SL-09 & SL-04 \\
\hline $\mathrm{Rb}$ & 247 & 323 & 202 & 221 & 238 & 212 & 273 & 133 \\
$\mathrm{Sr}$ & 81 & 68 & 68 & 80 & 88 & 85 & 81 & 60 \\
$\mathrm{~V}$ & 11 & 11 & 8 & 11 & 10 & 14 & 9 & 16 \\
$\mathrm{Cr}$ & $<20$ & $<20$ & $<20$ & $<20$ & $<20$ & $<20$ & $<20$ & $<20$ \\
$\mathrm{Co}$ & 90 & 157 & 200 & 175 & 179 & 137 & 330 & 259 \\
$\mathrm{Ni}$ & $<20$ & $<20$ & $<20$ & $<20$ & $<20$ & $<20$ & $<20$ & $<20$ \\
$\mathrm{Cu}$ & $<10$ & $<10$ & $<10$ & $<10$ & $<10$ & $<10$ & $<10$ & $<10$ \\
$\mathrm{Zn}$ & $<30$ & 50 & 40 & 30 & 40 & 30 & 40 & 50 \\
$\mathrm{Ga}$ & 21 & 22 & 21 & 22 & 20 & 23 & 23 & 22 \\
$\mathrm{Ge}$ & 1.9 & 1.9 & 1.5 & 1.9 & 1.7 & 1.9 & 1.9 & 2.6 \\
$\mathrm{Y}$ & 90.6 & 71.9 & 80.3 & 109 & 67.3 & 39.9 & 54.5 & 147 \\
$\mathrm{Zr}$ & 194 & 162 & 101 & 167 & 150 & 174 & 130 & 517 \\
$\mathrm{Nb}$ & 20.2 & 21.7 & 15.2 & 19.2 & 15.1 & 18.2 & 20.8 & 44.1 \\
$\mathrm{Sn}$ & 2 & 6 & 3 & 4 & 3 & 3 & 4 & 7 \\
$\mathrm{Ba}$ & 351 & 251 & 280 & 340 & 355 & 375 & 360 & 1,155 \\
$\mathrm{La}$ & 82.3 & 69.4 & 58.5 & 74.8 & 74.3 & 219.0 & 44.5 & 256.0 \\
$\mathrm{Ce}$ & 164 & 141 & 118 & 150 & 147 & 308 & 114 & 395 \\
$\mathrm{Eu}$ & 0.989 & 0.661 & 0.720 & 0.880 & 0.920 & 1.540 & 0.624 & 4.060 \\
$\mathrm{Sm}$ & 14.9 & 12.3 & 10.8 & 13.7 & 12.6 & 28.3 & 6.74 & 36.9 \\
$\mathrm{Nd}$ & 64.10 & 54.10 & 45.50 & 60.10 & 56.30 & 153.0 & 30.60 & 188.0 \\
$\mathrm{Lu}$ & 1.290 & 0.986 & 1.110 & 1.610 & 0.970 & 0.305 & 0.924 & 1.990 \\
$\mathrm{Yb}$ & 8.53 & 6.88 & 7.84 & 11.10 & 6.55 & 2.22 & 6.35 & 13.80 \\
$\mathrm{Gd}$ & 13.80 & 11.00 & 10.60 & 13.90 & 11.30 & 19.80 & 6.25 & 31.30 \\
$\mathrm{Ho}$ & 3.28 & 2.54 & 2.88 & 3.90 & 2.52 & 1.54 & 1.91 & 5.28 \\
\hline
\end{tabular}

Table 4. Geochronological data of the Salininha monzogranite.

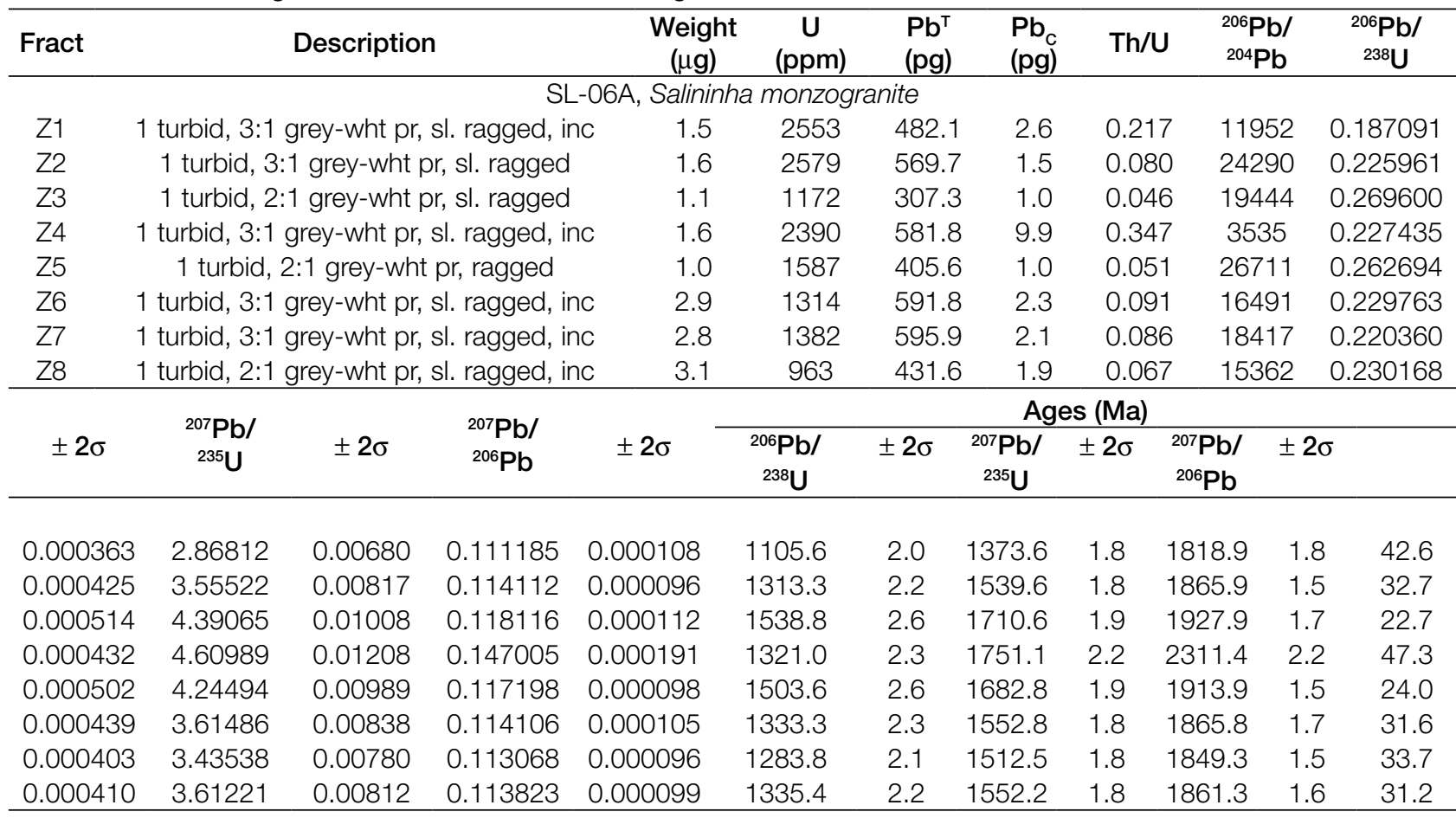

Wht: white; pr: generally prismatic; sl: slightly; inc: inclusions present (type unknown); all analyzed fractions represent best available optical quality zircon. All zircons underwent chemical abrasion pretreatment (after Mattinson, 2005); PbT: total amount (in picograms) of Pb; PbC: total measured common Pb (in picograms) assuming the isotopic composition of laboratory blank: 206/204 - 18.221; 207/204 - 15.612; 208/204 - 39.360 (errors of 2\%); Pb/U atomic ratios are corrected for spike, fractionation, blank, and, where necessary, initial common $\mathrm{Pb} ;{ }^{206} \mathrm{~Pb} /{ }^{204} \mathrm{~Pb}$ is corrected for spike and fractionation; $\mathrm{Th} / \mathrm{U}$ : the model value calculated from radiogenic ${ }^{208} \mathrm{~Pb} /{ }^{206} \mathrm{~Pb}$ ratio and ${ }^{207} \mathrm{~Pb} /{ }^{206} \mathrm{~Pb}$ age, assuming concordance; Disc. (\%): percent discordance for the given ${ }^{207} \mathrm{~Pb} /{ }^{206} \mathrm{~Pb}$ age; uranium decay constants are from Jaffey et al. (1971). 

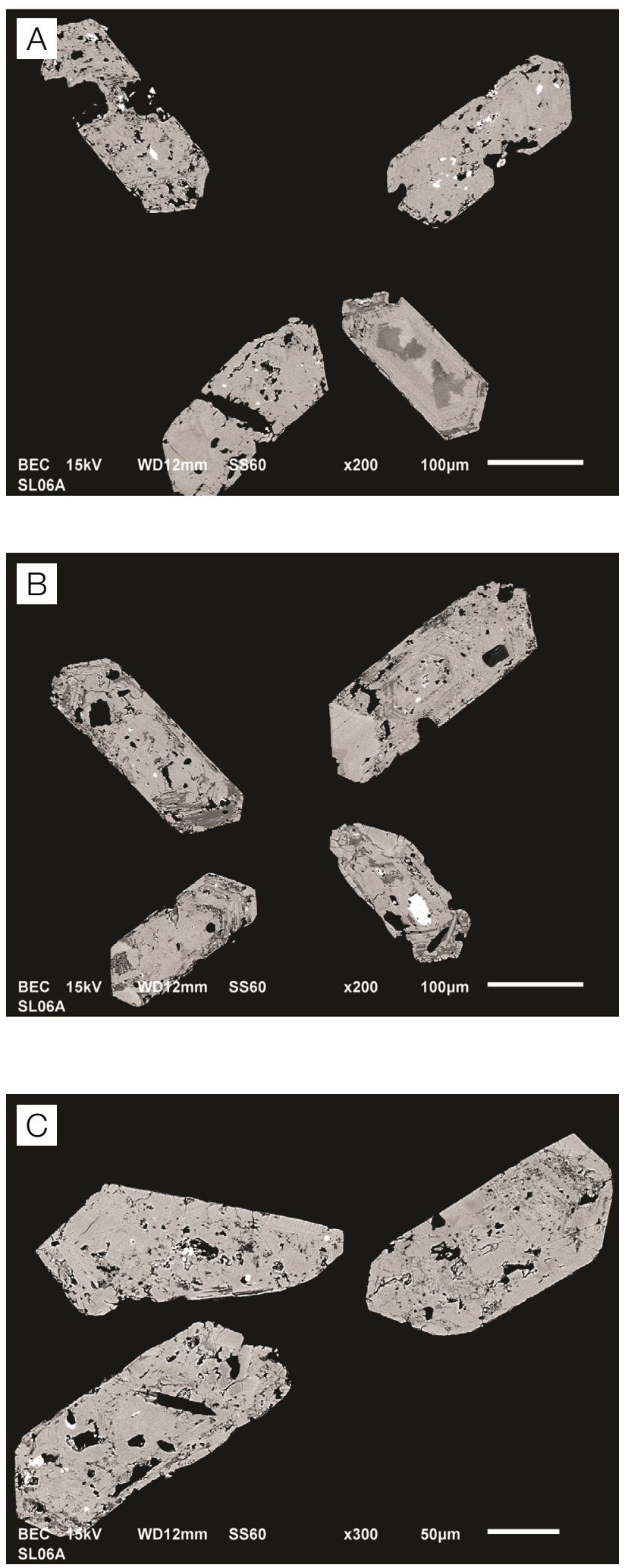

Figure 10. Backscattered (BSE) images of the zircons of Salininha monzogranite. (A) Grains 1-4. (B) Grains 5-8. (C) Grains 9-11. post-collisional settings. With that said, it is possible to verify that the Salininha pluton plots entirely in the A2 field of both Y-Nb-Ce and Y-Nb-Ga diagrams of Eby (1992) (Figure 13), indicating that they are related to post-orogenic settings. This idea is also supported by the $\mathrm{Rb} v s$. $\mathrm{Y}+\mathrm{Nb}$ and $\mathrm{Nb} v s$. $\mathrm{Y}$ diagrams of Pearce et al. (1984) (Figure 14).

The Salininha monzogranite is composed, on average, of quartz $(27-35 \%)$, albite $(15-23 \%)$, microcline $(18-26 \%)$, biotite $(9-20 \%)$ and muscovite $(2-3 \%)$. Hornblende, epidote, opaques and zircon occur as accessory minerals. The monzogranite locally contains xenoliths of the host rock from the enclosing Gavião Complex orthogneiss. The pluton itself, however, is undeformed, demonstrating that it is post-tectonic in origin. An ID-TIMS $\mathrm{U}-\mathrm{Pb}$ (zircon) crystallization age of $2003 \pm 4 \mathrm{Ma}$ for this massive intrusion establishes a minimum time constraint for the regional deformation event that immediately preceded this magmatism.

Lithogeochemical data indicate that the intrusion crystallized from a mildly peraluminous magma, in a post-collisional, within-plate setting. It has relatively high contents of silica $\left(71.6-75.0 \mathrm{wt} . \% \mathrm{SiO}_{2}\right)$, and strongly developed negative Eu anomalies suggesting that it is the product of a substantial fractionation process that involved separation of magma from a feldspathic residue. The Salininha

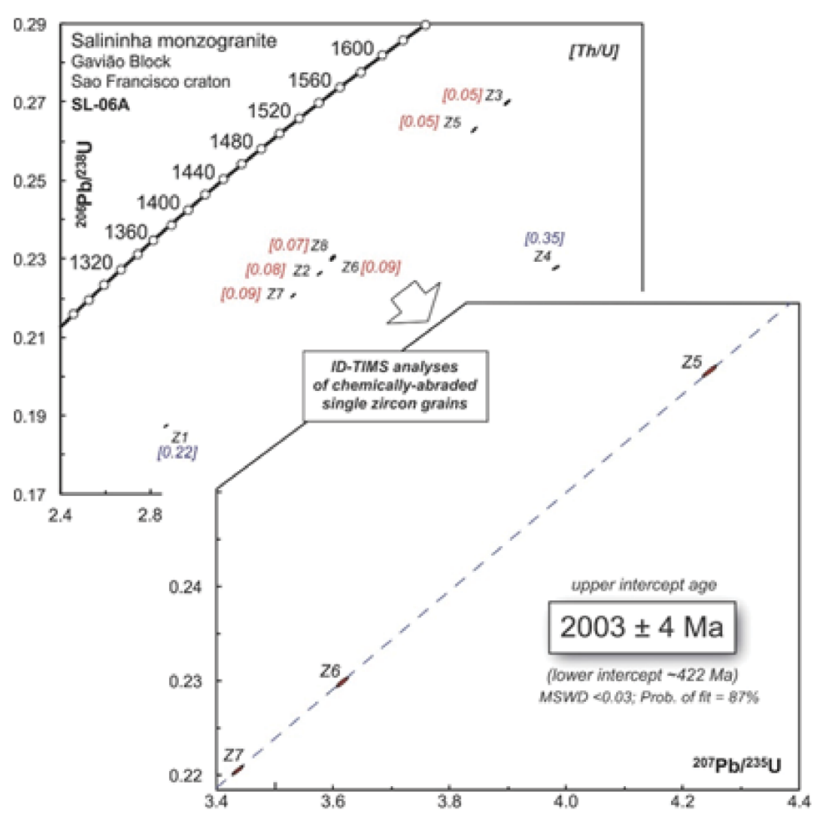

Figure 11. $\mathrm{U}-\mathrm{Pb}$ concordia diagram showing $\mathrm{U}-\mathrm{Pb}$ single grain thermal ionization mass spectrometer, via isotopic dilution (ID-TIMS), zircon analyses from sample SL-06A. The data indicate an age of ca. 2003 Ma for the Salininha monzogranite. 
pluton appears to be correlated with a number of other regional post-tectonic granites that occur elsewhere in the GB, such as Caculé and Espírito Santo intrusions (Leal et al., 1998); whether all of these bodies could be related to a larger plutonic body at depth is presently unknown.

A number of textural features (quartz veins, alteration of biotite and plagioclase, intense alteration of zircon) suggests that the level of exposure of the Salininha pluton reflects the possible proximity to an outer or upper carapace of a fractionating granitic magma chamber, where exsolving magmatic/hydrothermal fluids were capable of altering the late-crystallizing monzogranites. These fluids appear to have had little effect on the REE abundances and patterns within this suite.

The $2003 \pm 4 \mathrm{Ma}$ age is in good agreement with other regional Paleoproterozoic plutonic rocks (e.g., Caculé and Espírito Santo granitoids) that appear to characterize peak-metamorphism and anatexis associated with the Paleoproterozoic orogeny of the GB.

\section{ACKNOWLEDGEMENTS}

The authors acknowledge financial support by Brazilian National Council for Scientific and Technological Development (Conselho Nacional de Desenvolvimento Científico e Tecnológico - $\mathrm{CNPq}$ - Process no. 201805/2013-8), related to the Science without Borders Program's sandwich graduation scholarship for GordilhoBarbosa, R., that allowed the realization of the oxides, minor and trace elements analyses at Activation Laboratories, Canada. Also, we would like to thank Serviço Geológico do Brasil (CPRM) for making the polished thin sections used for this research and an anonymous reviewer for the useful comments for the improvement of this article.
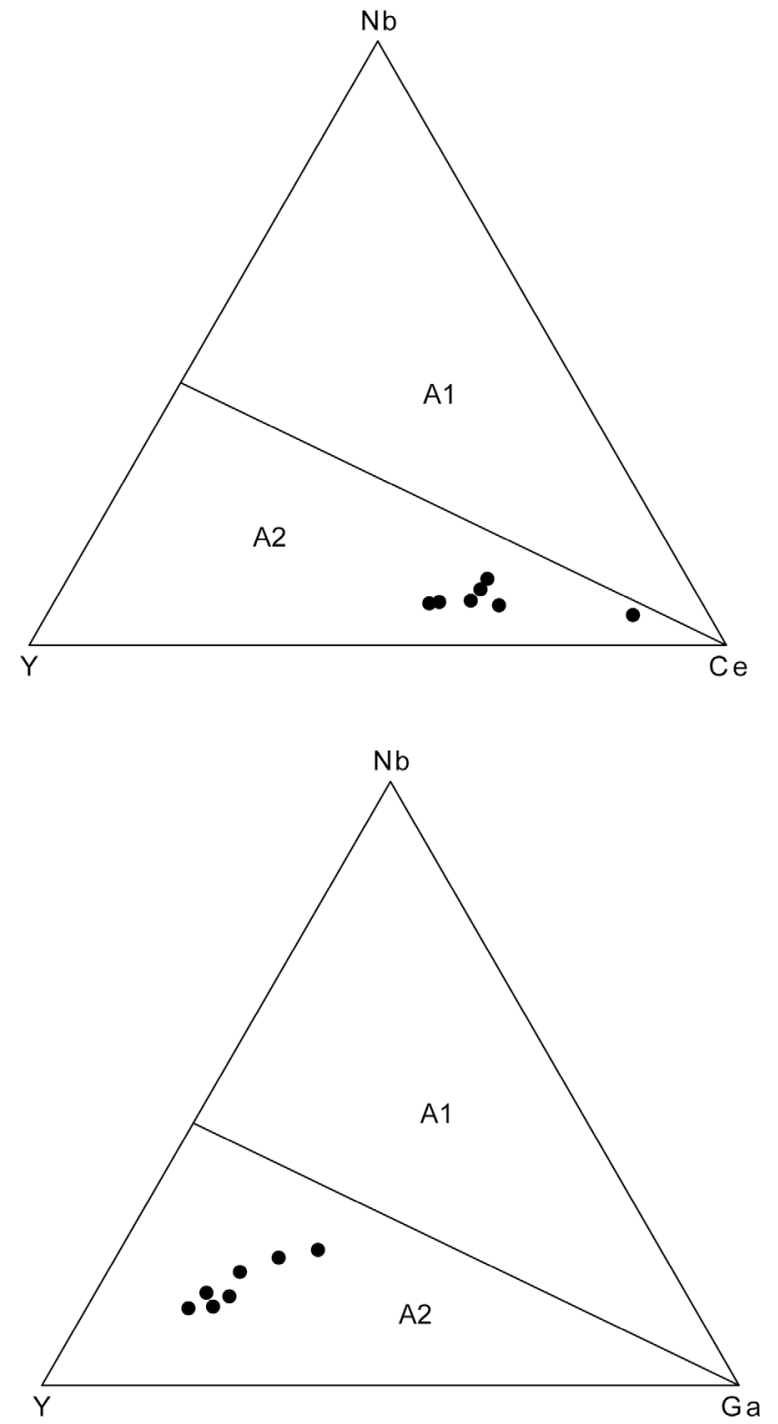

Figura 13. (A) and (B) $\mathrm{Y}-\mathrm{Nb}-\mathrm{Ce}$ and $\mathrm{Y}-\mathrm{Nb}-\mathrm{Ga}$ diagrams (Eby, 1992) indicating that the Salininha monzogranite is A2-type.
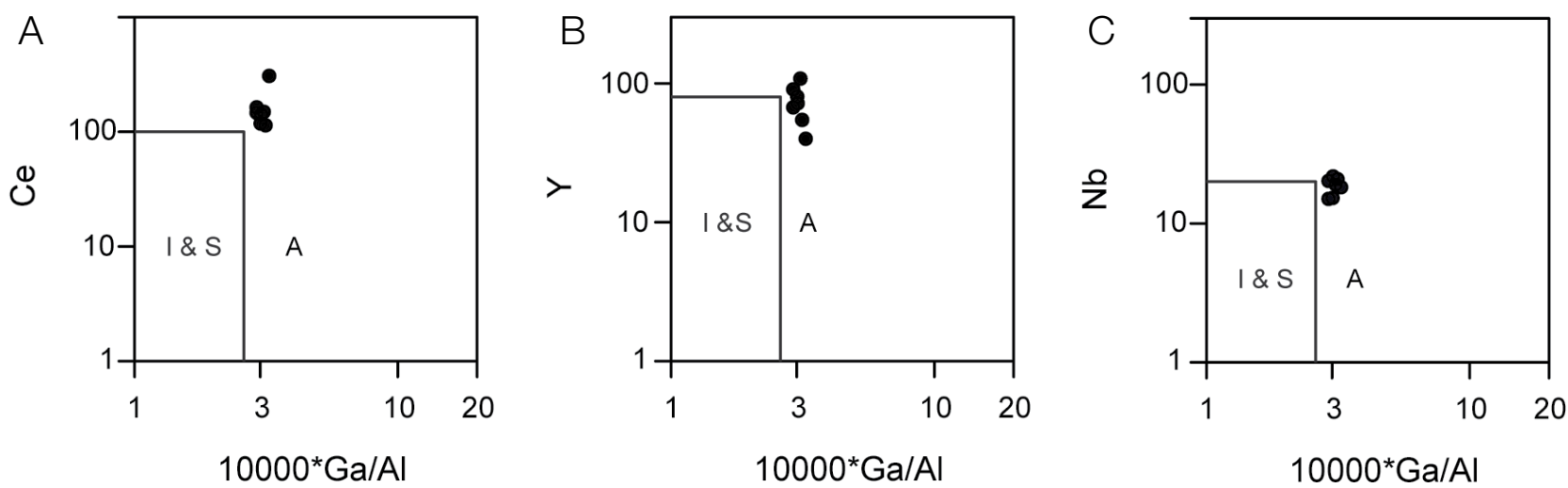

Figure 12. (A), (B) and (C) $\mathrm{Ce}, \mathrm{Y}$ and $\mathrm{Nb}$ vs. $10,000^{*} \mathrm{Ga} / \mathrm{Al}$ diagrams indicating the $\mathrm{A}$-type affinity of the Salininha monzogranite. 

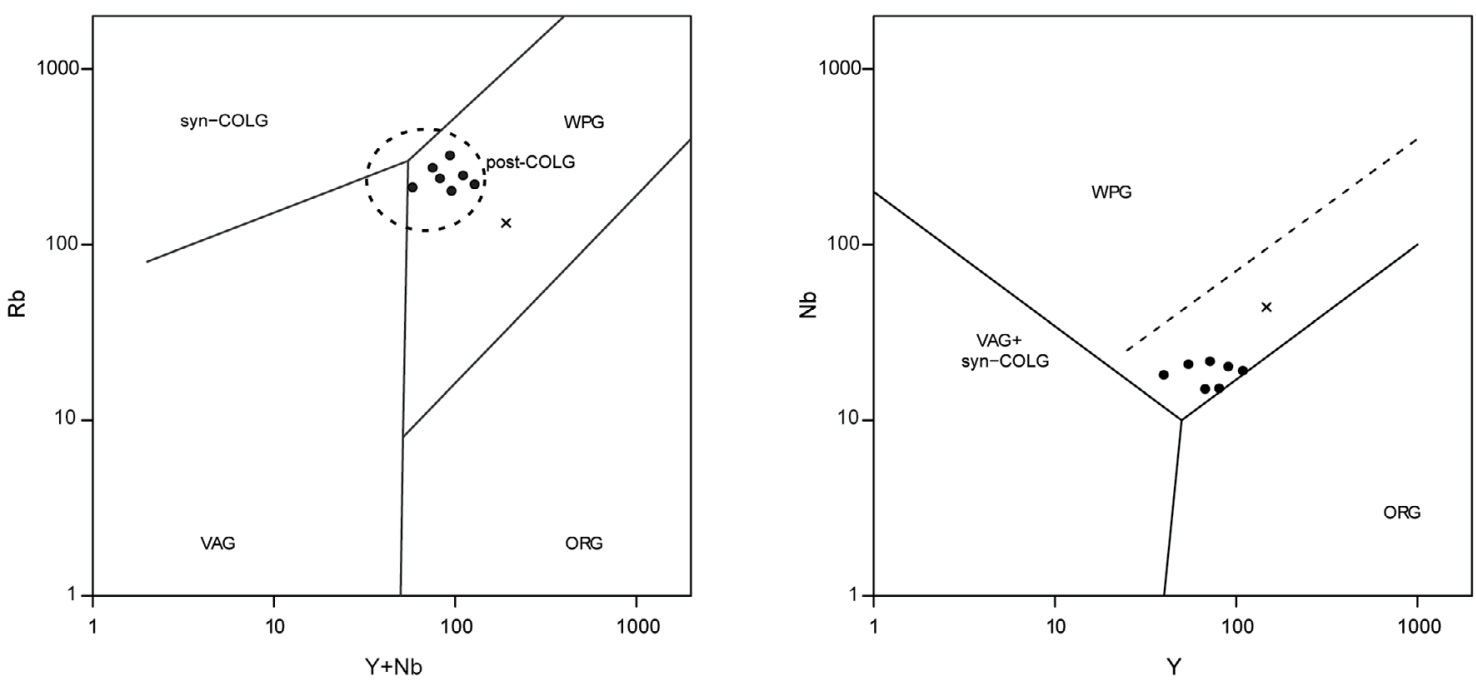

Figure 14. (A) and (B) Rb vs. $\mathrm{Y}+\mathrm{Nb}$ and $\mathrm{Nb}$ vs. $\mathrm{Y}$ diagrams (Pearce et al., 1984) indicating that the Salininha monzogranite is post-collisional.

\section{REFERENCES}

Almeida, F. F. M. (1977). O Cráton do São Francisco. Revista Brasileira de Geociências, 7(4), 349-364.

Arcanjo, J. B. A., Martins, A. M., Loureiro, H. C., Delgado, I. M., Souza, J. D., Neves, J. P., Oliveira, J. E., Teixeira, L. R., Varela, P. H., Gomes, R. D., Santos, R. A., Melo, R. C. (2005). Vale do Paramirim, Bahia: geologia e recursos minerais. Salvador: CBPM/CPRM. (Série Arquivos Abertos, v. 22).

Barbosa, J. S. F., Barbosa, R. G. (2017). The Paleoproterozoic Eastern Bahia Orogenic Domain. In: M. Heilbron, U. G. Cordani, F. F. Alkmim (Eds.), São Francisco Craton, Eastern Brazil. Regional Geology Reviews, p. 57-69. Switzerland: Springer, Cham. https://doi.org/10.1007/978-3-319-01715-0_4

Barbosa, J. S. F., Cruz, S. C. P., Leal, A. B. M. (2009). Mapeamento geológico e levantamento dos recursos minerais da Folha Caetité, escala 1:100.000. Programa Levantamentos Geológicos Básicos. Salvador: CPRM/UFBA/FAPEX.

Barbosa, J. S. F., Cruz, S. C. P., Souza, J. S. (2012). Terrenos Metamórficos do Embasamento. In: J. S. F. Barbosa, J. F. Mascarenhas, L. C. Corrêa-Gomes, J. M. L. Dominguez, J. S. Souza (Eds.), Geologia da Bahia: pesquisa e atualização, p. 101-199. Salvador: CPBM; UFBA.

Barbosa, J. S. F., Pinto, M. S., Cruz, S. C. P., Souza, J. S. (2012). Granitoides. In: J. S. F. Barbosa, J. F. Mascarenhas, L. C. Corrêa-Gomes, J. M. L. Dominguez, J. S. Souza (Eds.),
Geologia da Bahia: pesquisa e atualização, p. 327-394. Salvador: CBPM; UFBA.

Barbosa, J. S. F., Sabaté, P. (2002). Geological Features and the Paleoproterozoic Collision of four Archaean Crustal Segments of the São Francisco Cráton, Bahia, Brazil. A Synthesis. Anais da Academia Brasileira de Ciências, 74(2), 343-359.

Barbosa, J. S. F., Sabaté, P. (2003). Colagem Paleoproterozóica de placas arqueanas do Cráton do São Francisco na Bahia. Revista Brasileira de Geociências, 33(1 Suppl.), 7-14.

Barbosa, J. S. F., Sabaté, P. (2004). Archean and Paleoproterozoic crust of the São Francisco Craton, Bahia, Brazil: Geodynamic features. Precambrian Research, 133(1-2), 1-27. https://doi. org/10.1016/j.precamres.2004.03.001

Boynton, W. V. (1984). Cosmochemistry of the Rare Earth elements: meteorite studies. In: P. Henderson (Ed.), Rare Earth Element geochemistry, p. 63-114. Developments in Geochemistry. https://doi.org/10.1016/B978-0-444-42148-7.50008-3

Brito, D. C. (2007). Geologia, petrografia e litogeoquímica dos diques máficos que ocorrem na porção sudoeste da Chapada Diamantina, Bahia-Brasil. Dissertation (Mastering). Salvador: Instituto de Geociências - UFBA.

Cruz, S. C. P., Alkmim, F. F. (2007). A história de inversão do aulacógeno do Paramirim contada pela sinclinal de Ituaçu, extremo sul da Chapada Diamantina (BA). Revista Brasileira de Geociências, 37(4), 92-110. 
Cruz, S. C. P., Barbosa, J. S. F., Pinto, M. S., Peucat, J. J., Paquette, J. L., Souza, J. S., Martins, V. S., Chemale Júnior, F., Carneiro, M. A. (2016). The Siderian-Orosirian magmatism in the Gavião Paleoplate, Brazil: U-Pb geochronology, geochemistry and tectonic implications. Journal of South American Earth Sciences, 69, 43-79. https://doi.org/10.1016/j. jsames.2016.02.007

Cunha, J. C., Barbosa, J. S. F., Mascarenhas, J. F. (2012). Greenstone Belts e sequências similares. In: J. S. F. Barbosa, J. F. Mascarenhas, L. C. Corrêa-Gomes, J. M. L. Dominguez, J. S. Souza (Eds.), Geologia da Bahia: pesquisa e atualização, p. 203-325. Salvador: CBPM; UFBA.

Eby, G. N. (1992). Chemical subdivision of the A-type granitoids: petrogenetic and tectonic implications. Geology, 20(7), 641644. https://doi.org/10.1130/0091-7613(1992)020\%3C064 1:CSOTAT\%3E2.3.CO;2

Frost, B. R., Barnes, C. G., Collins, W. J., Arculus, R. J., Ellis, D. J., Frost, C. D. (2001). A Geochemical Classification for Granitic Rocks. Journal of Petrology, 42(11), 2033-2048. https://doi.org/10.1093/petrology/42.11.2033

Frost, C. D., Frost, B. R. (2013). Proterozoic ferroan feldspathic magmatism. Precambrian Research, 228, 151-163. https://doi.org/10.1016/j.precamres.2013.01.016

Harker, A., (1909). The natural history of the igneous rocks. New York: Cambridge University.

Jaffey, A.H., Flynn, K.F., Glendenin, L.E., Bentley, W.C., Essling, A.M. (1971). Precision measurement of half-lives and specific activities of $235 \mathrm{U}$ and $238 \mathrm{U}$. Physical Review, 4, 1889-1906. https://doi.org/10.1103/PhysRevC.4.1889

Kemp, A. I. S., Hawkesworth, C. J. (2003). Granitic perspectives on the generation and secular evolution of the continental crust. In: H. D. Holland, K. K. Turekian (Eds.), Treatise in Geochemistry, v. 3, p. 349-410. Oxford: Elsevier. https://doi.org/10.1016/B0-08-043751-6/03027-9

Leal, L. R. B., Teixeira, W., Cunha, J. C., Leal, A. B. M., Macambira, M. J. B., Rosa, M. L. S. (2000). Isotopic signatures of paleoproterozoic granitoids of the Gavião Block and implications for the evolution of the São Francisco Craton, Bahia, Brazil. Revista Brasileira de Geociências, 30(1), 66-69.

Leal, L. R. B., Teixeira, W., Cunha, J. C., Macambira, M. J. B. (1998). Archean tonalitic-trondhjemitc and granitic plutonism in the Gavião Block, São Francisco Craton, Bahia, Brazil: Geochemical and geochronological characteristics. Revista Brasileira de Geociências, 28(2), 209-220.
Loiselle, M., Wones, D. (1979). Characteristics and origin of anorogenic granites. Geological Society of America. Abstracts with programs, v. 11, p. 468.

Martin, H., Peucat, J. J., Sabaté, P., Cunha, J. C. (1997). Crustal Evolution in the Early Archean of South America: example of the Sete Voltas massif, Bahia state, Brazil. Precambrian Research, 82(1-2),35-62. https://doi.org/10.1016/S0301-9268(96)00054-X

Mattinson, J. (2005). Zircon U-Pb chemical abrasion (CA-TIMS) method: Combined annealing and multi-step partial dissolution analysis for improved precision and accuracy of zircon ages. Chemical Geology, 220(1), 47-66. http://dx.doi.org/10.1016/j.chemgeo.2005.03.011

McDonough, W. F., Sun, S. S. (1995). The composition of the Earth. Chemical Geology, 120 (3-4), 223-253.

Palmeira, D. S. (2010). Petrografia do sienogranito Broco: evidência de fusão crustal no Greenstone Belt Ibitira-Ubiraçaba, Ibiassucê, Bahia. Monograph. Salvador: Instituto de Geociências - UFBA.

Pearce, J. A., Harris, N. B. W., Tindle, A. G. (1984). Trace element discrimination diagrams for the tectonic interpretation of granitic rocks. Journal of Petrology, 25, part 4, 956-983.

Santos-Pinto, M. A. (1996). Le recyclage de la croûte continentale archéenne: exemple du bloc du Gavião - Bahia, Brésil. Mémoires des Géosciences Rennes, 75, 193.

Santos-Pinto, M. A., Peucat, J. J., Martin, H., Barbosa, J. S. F., Fanning, C. M., Cocherie, A., Paquette, J. L. (2012). Crustal evolution between 2.0 and $3.5 \mathrm{Ga}$ in the southern Gavião block (Umburanas-Brumado-Aracatu region), São Francisco Craton, Brazil: A 3.5-3.8 Ga proto-crust in the Gavião block? Journal of South American Earth Sciences, 40, 129-142. https://doi.org/10.1016/j.jsames.2012.09.004

Santos-Pinto, M. A., Peucat, J. J, Martin, H., Sabaté, P. (1998). Recycling of the Archean continental crust: the case study of the Gavião Block, Bahia, Brazil. Journal of South American Earth Sciences, 11(5), 487-498. http://dx.doi. org/10.1016/S0895-9811(98)00029-7

Shand, S. J. (1943). Eruptive Rocks: their genesis composition, classification, and their relations to ore deposits. New York: John Wiley.

Silva, M. G., Cunha, J. C. (1999). Greenstone belts and equivalent volcano-sedimentary sequences of the São Francisco Craton, Bahia, Brazil - Geology and Mineral Potential. In: M. G. Silva, A. Misi A. (Eds), Base Metal Deposits of Brazil, p. 92-99. Salvador: SBG. 
Streckeisen, A. (1976). To Each Plutonic Rock its Proper Name. Earth Sciences Review, 12(1), 1-33. https://doi. org/10.1016/0012-8252(76)90052-0

Turpin, L., Maruejol, P., Cuney, M. (1988). U-Pb, Rb-Sr and $\mathrm{Sm}-\mathrm{Nd}$ chronology of granitic basement, hydrothermal albitites and uranium mineralization (Lagoa Real, SouthBahia, Brazil). Contributions to Mineralogy and Petrology, 98(2), 139-147. https://doi.org/10.1007/BF00402107

Whalen, J, Currie, K., Chappell, B. (1987). A-type granites:geochemical characteristics, discrimination and petrogenesis; Contributions to Mineralogy and Petrology, 95(4), 407-419. https://doi.org/10.1007/BF00402202

Whitney, D. L., Evans, B. W. (2010). Abbreviations for names of rock-forming minerals. American Mineralogist, 95(1), 185-187. https://doi.org/10.2138/am.2010.3371

Zincone, S. A, Oliveira, E. P. (2017). Field and geochronological evidence for origin of the Contendas-Mirante Supracrustal Belt, São Francisco Craton, Brazil, as a Paleoproterozoic foreland basin. Precambrian Research, 299, 117-131. https:// doi.org/10.1016/j.precamres.2017.07.031 